\title{
PROGRAM INTERVENSI PENGEMBANGAN KECAKAPAN BERBICARA ANAK DOWN SYNDROME
}

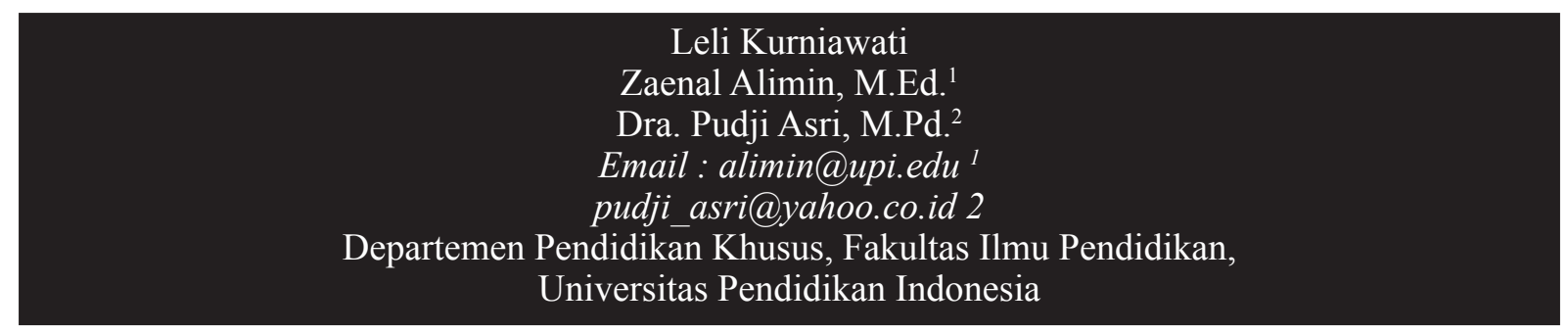

\section{ABSTRAK}

Kemampuan berbicara dan berbahasa merupakan kemampuan awal yang harus dimiliki anak sebagai modal untuk dapat berinteraksi dan berkomunikasi. Intervensi diberikan bagi mereka yang mengalami hambatan dalam perkembangan termasuk perkembangan bicara bahasa pada anak down syndrome. Penelitian ini bertujuan untuk merumuskan program intervensi yang sesuai dengan perkembangan dan kebutuhan anak down syndrome. Penelitian ini untuk mengetahui perkembangan bicara pada anak down syndrome serta upaya yang telah dilakukan untuk membantu mengembangkan kemampuan berbicara mereka. Penelitian ini menggunakan metode campuran (mixed methods) dengan desain sequential exploratory, yakni sebuah desain penelitian yang menggabungkan penelitian kualitatif dan kuantitatif secara bertahap. Hasil dari penelitian ini menunjukan bahwa kemampuan berbicara anak masih terbatas pada pengucapan satu kata tanpa adanya penangangan khusus. Program intervensi yang dirancang terdiri dari aspek pemahaman kosakata, sintaksis dan sematis yang disusun berdasarkan perkembangan anak. Hasil dari pelaksanaan program ini menunjukan peningkatan bicara anak pada beberapa kata. Program ini dapat dilaksanakan dalam proses belajar mengajar di kelas. Perhatian yang lebih pada anak dapat membantu anak down syndrome meningkatkan kemampuan berbicaranya.

Kata Kunci : program intervensi, kecakapan berbicara, down syndrome, mixed methods

\section{SPEAKING CAPABILITYS DEVELOPMENT INTERVENTION PROGRAM FOR CHILDREN WITH DOWN SYNDROME}

\begin{abstract}
Speech and language is an initial capability to be owned subsidiaries as capital to be able to interact and communicate. Intervention is given to those who experience barriers to development including speech development of language in children with Down syndrome. This study aims to formulate intervention programs in accordance with the development and needs of children with Down syndrome. This study to determine the speech development in children with down syndrome and the efforts that have been undertaken to help develop their speaking skills. This study used mixed methods with sequential exploratory design, which is a design study that combines qualitative and quantitative research gradually. Results from this study showed that the ability to speak the child is still limited to the pronunciation of the word without any special handling. The program consists of interventions designed aspects of understanding of the vocabulary, syntax and schematically drawn based on the child's development. The results of the implementation of this program showed improvement in the children speak a few words. This program can be implemented in teaching and learning in the classroom. More attention in children can help children with Down syndrome improve speaking ability.

Keywords: intervention program, speech intelligibility, down syndrome, mixed methods
\end{abstract}




\section{PENDAHULUAN}

Klasifikasi anak tunagrahita salah satunya adalah anak-anak down syndrome, yakni "suatu kondisi keterbelakangan perkembangan fisik dan mental yang diakibatkan adanya abnormalitas perkembangan kromosom.” (Clinic, 2012).

Kemampuan berbicara dan berbahasa merupakan kemampuan awal yang harus dimiliki anak sebagai modal untuk dapat berinteraksi dan berkomunikasi. Keterlambatan berbicara sering dikaitkan dengan gangguan perkembangan, gangguan perilaku, gangguan motorik oral dan gangguan fungsi lainnya, bila berbagai gangguan yang terjadi hampir bersamaan tersebut tidak disikapi dengan baik, maka akan mengganggu tumbuh dan kembangnya anak di masa depan (Judarwanto, 2009). Anak down syndrome mengalami hampir seluruh gangguan perkembangan yang dikaitkan dengan keterlambatan bicara tersebut, mereka cenderung akan berbicara melalui perilakunya, bersikap sesuai keinginannya yang lebih sering membuat teman-teman atau orang yang berada didekatnya mengalami kesulitan saat mereka bersikap karena ketidakpahaman mereka tentang apa yang anak inginkan.

Berdasarkan hasil temuan di lapangan, di sebuah sekolah terdapat seorang anak down syndrome dengan kondisi berbicara yang masih terlambat, untuk itu diperlukan sebuah program khusus untuk membantu anak dalam memperbaiki kondisi berbicara dan berbahasanya. Program ini berupa program intervensi, sebuah program yang dirancang untuk memberikan stimulasi pada anak berdasarkan kondisi anak down syndrome dalam perkembangan berbicara dan berbahasa. Tujuannya untuk memberikan stimulasi dan membatu memperbaiki kemampuan berbicara dan berbahasa anak down syndrome agar anak dapat berkomunikasi verbal dengan baik serta dapat aktif secara sosial, misalnya pada teman sebayanya.

\section{KAJIAN TEORI \\ Perkembangan Bicara pada Anak}

Bicara merupakan bentuk bahasa yang menggunakan artikulasi atau katakata untuk menyampaikan suatu maksud. Sedangkan kemampuan berbicara adalah "kemampuan mengucapkan bunyi-bunyi artikulasi atau mengucapkan kata-kata untuk mengekspresikan, menyatakan, menyampaikan pikiran, gagasan dan perasaan" (Arsjad \& S, 1998, hal. 17).

Seotjiningsih merangkum beberapa perkembangan berbicara yang dikemukakan ahli kedalam beberapa tahapan, yang dimulai sejak anak lahir hingga masa anak-anak.

1. Permulaan Bicara

Kira-kira pada usia 1-2 bulan bayi mendekut (cooing) dalam bentuk suara "oo..", “coo.." Atau "goo.." selanjutnya meraban (mengoceh), menggabungkan kombinasi konsonan vokal seperti "ba..ba.. ba..ba..”, “da..da..da..da..". Van Ginneken mengemukakan bahwa anak mulai menirukan kata-kata sekitar akhir tahun pertama yang disebul echo-lalie.

2. Kalimat satu kata (pralingual)

Sekitar tahun pertama, yaitu antara 10-15 bulan (rata-rata 13 bulan), anak mengucapkan kata-kata yang pertama. Satu 
kalimat anak harus dianggap satu kalimat penuh. Misalnya anak mengatakan "kursi" maka hal itu dapat berarti "saya mau duduk di kursi" atau "mama harus duduk di kursi" atau "saya minta kursi untuk naik" atau mengatakan "kue" dapat berarti "saya mau kue itu" atau "itu kue". Kata yang diucapkan tidak bisa dipandang penyebutan objek murni, tetapi mempunyai isi psikologis yang bersifat intelektual, emosional dan sekaligus volisional, yaitu anak menunjukan mau atau tidak mau.

Kata-kata pertama bayi meliputi nama orang yang penting baginya (papa mama), binatang yang lazim (kucing, disebut istilah "pus..") dan beberapa kata lain; ternyata merupakan kata-kata pertama bayi yang lahir 50 tahun yang lalu dan juga kata-kata pertama bayi-bayi masa kini (Santrock, 2012, hal. 191)

3. Kalimat dua kata (Lingual awal)

Sekitar bulan ke-18 hingga ke-24, anak mulai mengeluarkan kalimat dua kata yang pertama. Ada dua kelompok kata yang spesifik yaitu kata-kata pivot dan kata-kata terbuka. Kata-kata pivot yang sama dapat berbeda-beda artinya dalam kombinasi dengan kata terbuka yang berlainan. Kalimat dua kata ini bersifat telegrafis karena menghilangkan banyak bagian gramatikal dan sangat ringkas. Pembicaraan telegrafis adalah penggunaan kata-kata pendek dan singkat tanpa tanda-tanda gramatikal seperti kata keterangan, kata kerja bantu dan kata penghubung lainnya.

\section{Faktor-faktor yang Mempengaruhi}

Perkembangan Bicara

Keterlambatan atau gangguan berbicara anak tidak akan terjadi begitu saja, ada beberapa faktor yang dapat mempengaruhi perkembangan seorang anak dalam kemampuan berbicara (Hurlock, 2012, hal. 112), diantaranya :

1. Intelegensi (Anak-anak yang cerdas cenderung lebih cepat dalam penguasaan bahasanya)

2. Jenis disiplin (Anak-anak yang dibesarkan dengan pola disiplin yang lemah cenderung lebih banyak berbicara daripada anak yang dibesarkan dengan pola disiplin yang keras)

3. Posisi urutan (Anak sulung lebih banyak berbicara)

4. Besarnya keluarga (anak tunggal dari keluarga kecil lebih baik)

5. Status sosial ekonomi

6. Status ras

7. Dwibahasa (Pembicaraan anak dengan dwibahasa lebih terbatas dengan teman sebayanya)

8. Penggolongan peran seks (Anak lakilaki diharapkan lebih sedikit berbicara dibandingkan anak perempuan)

Disaat anak-anak yang lain mengalami perkembangan bahasa yang pesat dan dapat berkomunikasi dengan baik bersama orang-orang disekitarnya, anak-anak down syndrome akan mengalami perkembangan bahasa yang sebaliknya. Keterlambatan perkembangan bahasa ini disebabkan karena adanya hambatan dalam kognitif anak yang berdampak pada kemampuan dalam berbicara dan berbahasa.

Kemampuan berbicara bukanlah 
kemampuan yang berdiri sendiri tetapi saling berkaitan dengan kemampuan yang lain. Kegiatan berbicara berhubungan erat dengan kegiatan mendengarkan. Berbicara dan mendengarkan merupakan kegiatan komunikasi dua arah. Keefektifan berbicara tidak hanya ditentukan oleh si pembicara tetapi juga oleh pendengar. Untuk dapat berkomunikasi dengan orang lain, anak harus mengerti apa yang dikatakan orang lain, jika tidak dapat dimengerti orang lain pembicaraan tidak berhubungan dengan apa yang dikatakan orang lain hal ini akan merusak kontak sosialnya.

Beberapa hal juga perlu diperhatikan untuk mengembangkan kemampuan berbicara anak, yaitu :

a. Persiapan fisik dan mental untuk berbicara

b. Bimbingan, meliputi model yang baik untuk ditiru (Orang di lingkungannya, televisi, radio, film, dsb)

c. Kesempatan untuk berpraktek atau berlatih bicara

d. Motivasi

Selain hal diatas, salah satu cara yang dapat dilakuakan oleh para orang tua dan pengasuh dalam meningkatkan perkembangan bahasa adalah dengan menyediakan suatu lingkungan dimana seorang anak membutuhkan komunikasi tanpa perlu dipaksa untuk melakukannya. (Dyer, 2004, hal. 5)

\section{Perkembangan Bicara dan Bahasa Anak}

\section{Down Syndrome}

a. Perkembangan Prabahasa

Perkembangan ini dimulai dari bayi baru lahir. Jika dilihat dari masa ini maka antara bayi normal dan bayi down syndrome hampir memiliki perkembangan yang sama.

b. Perkembangan Vokal

Anak Down syndrome usia 0-2 tahun tidak stabil dalam perkembangan babbling/ merabannya atau cenderung kurang aktif melakukannya dibanding anak- anak normal.

\section{c. Perkembangan Sosial dan Komunikasi}

Bayi down syndrome (0-18 bulan) memperlihatkan keterlambatan perkembangan kontak mata, begitu pula dalam perkembangan merabannya (Berger \& Cunninghan dalam Pruthi, 2007). Pada usia satu tahun lebih mereka mulai lebih dominan menggunakan penglihatannya dibandingkan menggunakan anggota tubuh lainnya untuk mengeksplorasi lingkungan. Bayi down syndrome (18 bulan) juga menunjukkan ketertarikan dengan ibunya atau orang lain dengan kontak mata, namun mereka kesulitan berinteraksi dengan ibunya dan mainannya dalam waktu bersamaan. Perbedaan perkembangan pola interaksi semakin terlihat jelas ketika bayi down syndrome memasuki usia dua tahun lebih. Perbedaan tersebut direfleksikan dalam bentuk bermain dan komunikasi. Anak-anak down syndrome juga lebih focus kepada orang-orang disekitar dari pada objek bendanya ketika menginginkan sesuatu. Kondisi tersebut merefeksikan keterlabatan perkembangan bahasanya.

\section{d. Perkembangan Semantik}

Semantik adalah bagian dari struktur bahasa yang lebih menekan pada perkembangan pemahaman makna kata dan makna kata dalam satu kelompok/kalimat. Perkembangan perbendaharaan kata pada anak down syndrome ternyata sebanding 
dengan usia mentalnya, bahkan ada yang benar-benar tertinggal dikarenakan adanya hambatan ganda, yaitu gangguan bicara (Miller et al., 1994 dalam Gauri, 2007). anak down syndrome lebih menggunakan kata dasarnya atau pada tingkat dasar (misalnya mobil, kuda) tidak mencapai tingkat subordinatnya (contoh Mercedes, zebra) atau tingkat superordinat (misalnya, kendaraan, hewan).

e. Perkembangan Fonologis (Bunyi Bahasa)

Anak-anak tunagrahita cenderung memperlihatkan adanya gangguan artikulasi. Anak-anak down syndrome menunjukkan kesulitan pada aspek fonologis yang dapat berkaitan dengan keterlabatan perkembangan merabannya dan bisa juga diakibatkan keterlabatan perkembangan bahasanya secara umum.

\section{f. Perkembangan Tata Bahasa Awal}

Hasil penelitian lain menunjukkan bahwa ditemukan bahwa pada anak-anak down syndrome mampu merangkai dua kata menjadi ungkapan yang bermakna terjadi pada usia enam tahun.

\section{Program Intervensi Kecakapan Berbicara}

Intervensi adalah layanan terhadap anak yang mengalami resiko hambatan perkembangan dalam aspek motorik, komunikasi dan bahasa, sosial emosi, kognisi, dan persepsi sensori. Intervensi dimaksudkan untuk menetapkan cara-cara apakah yang patut dipergunakan untuk merencanakan perbaikan berdasarkan masalah yang ditemukan dalam proses diagnosa dan pemberian umpan balik. Intervensi diartikan segala langkah dan tindakan yang lebih baik dari cara-cara yang bersifat konvensional, sehingga kadang-kadang hanya tampak sebagai prinsip-prinsip umum yang berlaku dalam berbagai situasi (Smith et al, 1976). Interveni dapat memperbaiki masalah-masalah perkembangan yang ada dan mengantisipasi (sifatnya preventif). Intervensi bisa dilakukan bila telah diadakan identifikasi.

Ada beragam cara yang dapat dilakukan untuk membantu anak dalam mengoptimalkan kemampuan berbicara-nya, salah satunya melalui terapi wicara. Terapis wicara melakukan terapi pada masalah di bidang artikulasi; difluency (ketidaklancaran berbicara); gangguan makan, gangguan bunyi suara (sengau), serta gangguan bahasa reseptif dan ekspresif.

Cohen, Nadel, \& Madnick (2002, hal.410) mengungkapkan, jika pemberian intervensi sebaiknya dilakukan secara individu, seperti yang diungkapkannya "... because there is no one communication profile, there is no one treatment plan. Treatment should be individually designed to meet all of the communication needs of the child."

Pemberian treatmen ataupun intervensi secara individu akan lebih fokus pada perkembangan anak. Program yang dirancang secara individu itu akan menyesuaikan dengan perkembangan, kemampuan dan kebutuhan anak, karena perkembangan serta kemampuan pada setiap anak akan berbedabeda maka diperlukan pendekatan dan program yang berbeda pula. 


\section{METODE PENELITIAN}

\section{Desain Penelitian}

Metode yang digunakan dalam penelitian ini adalah metode kombinasi (mixed methods) dengan desain penelitian sequential exploratory.

\section{Partisipan dan Tempat Penelitian}

Pada penelitian ini yang menjadi subjek dalam penelitian adalah seorang anak down syndrome yang memiliki hambatan dalam berbicara. Penelitian ini juga melibatkan guru dan orang tua siswa dalam proses pengumpulan data yang diperlukan. Penelitian ini dilaksanakan di sebuah sekolah luar biasa di kota Bandung.

\section{Pengumpulan Data}

Pengumpulan data kualitatif menggunakan teknik observasi dan wawancara. Sedangkan pengumplan data kuantitatif, teknik pengumpulan data yang digunakan adalah tes. Bentuk tes yang digunakan adalah tes unjuk kerja. Tes ini dilakuan untuk mengetahui pengaruh dan perkembangan dari intervensi yang diberikan.

\section{Analisis Data}

Teknik analisis data Kualitatif dilakukan dengan cara mengumpulkan, memilah-milah dan mengklasifikasikan hasil catatan lapangan yang kemudian diklasifikasikan sesuai dengan kemampuan, kebutuhan serta hambatan yang dialami oleh subjek penelitian sebelum merumuskan program intervensi.

Draf instrumen yang telah dibuat dapat diterapkan dilapangan apabila instrumen yang telah dibuat tadi telah valid dari uji terlebih dahulu. Penilaian ini dimaksudkan untuk memberikan gambaran rasional program intervensi yang telah disusun itu akan efektif atau tidak jika diterapkan dilapangan.

Proses penelitian menggunakan pendekatan kuantitatif, maka data hasil penelitian yang diperoleh dioalah dan dianalisis kedalam statistik deskriptif dengan tujuan untuk memperoleh gambaran tentang hasil intervensi. Penyajian datanya dijabarkan dalam bentuk grafik atau diagram, dengan menggunakan analisis grafik ini diharapkan dapat melihat gambaran secara jelas bagaimana pelaksanaan program intervensi yang telah dibuat.

\section{TEMUAN DAN PEMBAHASAN}

\section{Kondisi anak down syndrome dalam kemampuan berbicara}

Berdasarkan hasil observasi, AY masih mengalami keterbatasan dalam berbicara. AY hanya mampu berkomunikasi verbal dengan kalimat satu kata, itupun terkadang hanya terdengar suku kata terakhir dalam kalimat yang diucapkannya. Kalimat satu kata maksudnya adalah AY hanya mampu mengucapkan satu kata, tapi kata tersebut memiliki banyak makna, seperti saat anak mengucapkan kata tas, itu dapat berarti jika bekal yang dibawanya ada di dalam tas atau jika tas miliknya tidak ada di kursi.

Seperti yang diungkapkan oleh Santrock (2012, hal. 191) "Kata-kata pertama bayi meliputi nama orang yang penting baginya (papa mama), binatang yang lazim (kucing, disebut istilah "pus..") dan beberapa kata lain; ternyata merupakan kata-kata pertama bayi yang lahir 50 tahun yang lalu dan juga katakata pertama bayi-bayi masa kini .“ 
Sesuai dengan perkembanganya, AY memerlukan bimbingan dan latihan dalam mengucapkan kata sebagai langkah awal dalam mengembangkan kemampuan berbicaranya sebelum membentuk kalimat yang lebih luas, seperti yang diungkapkan oleh Seotjiningsih bahwa perkembangan bicara anak dimulai dari mendekut (cooing) dalam bentuk suara, kemudian meraban (mengoceh), selanjutnya kalimat satu kata (pralingual), kalimat dua kata (Lingual awal), dan seterusnya.

\section{Proses pembelajaran yang diberikan guru saat ini terhadap anak down syndrome dalam mengajar bicara}

Di sekolah, guru mengajarkan anak dengan pengucapan vokal a,i,u,e,o untuk melatihnya dalam berbicara. Di dalam kelas AY terkadang suka bertanya sambil menunjuk, namun terkadang suka diabaikan oleh guru karena guru tidak mengerti apa yang dibicarakan oleh anak. Hal ini seolah tidak memberikan kesempatan berbicara pada anak, Hurlock menjelaskan bahwa salah satu hal penting dalam belajar berbicara adalah "kesempatan untuk berpraktek. Jika karena alasan apapun kesempatan berbicara dihilangkan, jika mereka tidak dapat membuat orang lain mengerti, mereka akan putus asa dan marah. Ini seringkali melemahkan motivasi mereka untuk belajar."

\section{Pengasuhan orang tua dirumah yang berkaitan langsung dengan proses berbicara anak down syndrome}

Berdasarkan pemaparan orang tua, tidak ada cara khusus yang dilakukan oleh orang tua di rumah untuk membantu anak dalam mengembangkan kemampuannya dalam berbicara, selama ini anak selalu diajak berbicara seperti biasa, hanya saja dengan dengan intonasi dan artikulasi yang jelas. Pada saat kita mengajak berbicarapun anak akan melakukan kontak mata meski hanya sebentar, setelah itu perhatiannya akan mudah teralihkan dengan lainnya.

Dari pemaparan yang orang tua berikan, anak tertarik pada animasi namun orang tua tidak memberikan perhatian yang lebih untuk mendampingi anak dalam menonton dan memberikan pengarahan dalam mengembangkan kemampuannya dalam berbicara, padahal dalam sebuah artikel dari Eka News, dengan judul artikel Anak Terlambat Bicara, Normalkah? Yang ditulis oleh (Nurima, 2010, hal. 1) menyebutkan bahwa "... terapis dapat menggunakan gambar, buku, obyek tertentu, atau kejadian di sekitar anak pada saat aktivitas berlangsung, untuk menstimulasi perkembangan bahasa...."

\section{Uji Validitas Program Intervensi}

Program yang telah dirancang tersebut kemudian di ujikan kepada ahli, berikut hasil penilaian ahli mengenai validitas program.

Berdasarkan hasil perhitungan tersebut, maka hasil validitas tersebut cukup valid. Program yang tidak sesuai tidak akan digunakan atau diganti sesuai dengan kebutuhan dan program yang diujikan pada anak akan dimulai dari menyebutkan kata dengan materi menyebutkan kata benda yang ada di sekitar anak. pemilihan kata benda karena penggunaannya yang sering dan lebih familiar dengan anak. 


\section{Hasil Penelitian Penerapan Program}

Setelah program dilaksanakan, hasil yang diperoleh menunjukan jika adanya perubahan dalam kemampuan pengucapan kata yang telah disediakan pada subjek. Hal ini ditunjukan dengan meningkatnya hasil persentase pada setiap pertemuan. Selain itu juga ada beberapa kata yang dapat diucapkan oleh subjek dengan lebih baik seperti kata tas dan bola (bowa) tanpa adanya bantuan dari orang lain. Bola menjadi mudah diucapkan karena anak menyukai benda tersebut, selain bola juga ada 'mobil (m-bi)' yang cukup sering diucapkannya. Hal ini berarti intervensi memang diperlukan agar kemampuan berbicara anak mengalami perkembangan, sejalan dengan tunjuan intervensi yakni meningkatkan dan mengoptimalkan perkembangan anak yang mengalami hambatan (Nawawi).

Sedangkan dalam aspek pemahaman anak mengenai benda yang ada pada kartu gambar menunjukan jika kemampuan anak dalam bahasa reseptiflebih baik dibandingkan kemampuannya dalam bahasa ekspresif. Hal ini ditunjukan dengan skor pada pemahaman kata yang lebih besar dan stabil dibandingkan dengan skor pada pengucapan kata.

Selain itu, hasil dari penerapan di lapangan menggambarkan jika penggunaan media gambar tidak dapat dijadikan sebagai satu-satunya media yang digunakan dalam pemberian intervensi. Dengan demikian, program ini dapat diterapkan oleh guru ditengah jam belajar mengajar di sekolah dengan atau tanpa melibatkan siswa lainnya, namun guru harus lebih memperhatikan penggunaan media sebagai alat bantu agar tidak ada kejenuhan saat pemberian intervensi.

\section{SIMPULAN DAN REKOMENDASI}

Berdasarkan hasil penelitian dapat di ambil beberapa kesimpulan, sebagai berikut:

1. Kondisi perkembangan bicara anak menunjukan kemampuan bicara pada tahap satu kata sebagai satu kalimat. Seperti kata tas yang meiliki banyak makna misalnya bekalnya di tas atau tasnya tidak ada di kursi. Kalimat satu kata yang diucapkan anak tidaklah utuh sebagai satu kata melainkan hanya suku kata yang terucap namun anak sudah mampu mengikuti perintah sederhana. Secara keseluruhan kemampuan reseptif AY lebih baik daripada kemampuan ekspresifnya.

2. Pembelajaran yang diberikan guru di kelas sudah membantu anak dalam mengembangkan kemampuan berbicaranya namun belum maksimal.

3. Orang tua selaku orang terdekat dengan anak kurang mengupayakan secara maksimal untuk mengembangkan kemampuan berbicara anak, selama ini orang tua hanya mengajak anak berbicara seperti biasa tanpa bimbingan khusus.

4. Program yang dirumuskan disesuaikan dengan perkembagan anak. Program yang disusun berdasarkan dengan tahapan perkembangan berbicara anak, dimulai dari pengucapan dan pemahaman kata.

5. Program yang dilaksanakan dilapangan adalah program pemahaman kosakata, kata yang dipilih adalah kata benda yang dapat ditemui di lingkungan kelas. Dari hasil keterlakasanaan program tersebut terlihat adanya peningkatan pengucapan beberapa kata seperti kata tas dan bola, meski untuk kata-kata yang lain tidak meningkat secara pesat. 


\section{Rekomendasi}

Berdasarkan hasil penelitian yang telah dilakukan, ada beberapa hal yang perlu penulis sarankan kepada berbagai pihak sebagai tindak lanjut dari hasil penelitian ini, yaitu sebagai berikut:

1. Saran kepada pihak guru

Pengadaan media dan perhatian khusus kepada anak diperlukan dalam membantu mengembangkan kemampuan berbicaranya. Oleh karena itu penulis sarankan agar guru mencoba membuat target yang mampu dicapai siswa seuai dengan kemmpuannya dalam berbicara, selalu memberikan perhatian dan kesempatan pada anak tidak perlu lama, namun memberikan perhatian yang cukup. Penggunaan media dalam programintervensi dapat disesuaikan oleh guru melihat kondisi siswa.

\section{Saran untuk Orang Tua}

Melihat perkembangan anak yang terlambat, sebaiknya orang tua memberikan penanganan dan perhatian khusus pada anak, misalnya dengan diikutkan terapi berbicara. Pemberian dan penanganan terapi yang tepat dapat membantu dalam perkembangan berbicaranya.

\section{Saran untuk penelitian selanjutnya}

Untuk peneliti selanjutnya yang berminat untuk melaksanakan kembali penelitian berdasarkan pokok penelitian yang sama diharapkan adanya inovasi dalam mengembangkan program sehingga dapat lebih membantu mengembangkan kemampuan berbicara anak down syndrome. Selain itu, jika memungkinkan jumlah subjek penelitian bisa ditambah.

\section{DAFTAR PUSTAKA}

Arsjad, M. G., \& S, M. U. (1998). Pembinaan Kemampuan Bebicara Bahasa Indonesia. Jakarta: Erlangga.

Cohen, W. I., Nadel, L., \& Madnick, M. E. (2002). Down Syndrome Visions for the 21 st Century. New York: Wiley-Liss, Inc. Creswell, J. W. (2010). Research Design :

Pendekatan Kualitatif, Kuantitatif dan

Mixed. Yogyakarta: Pustaka Pelajar.

Durand, V. M., \& Barlow, D. H. (2007).

Intisari Psikologi Abnormal (Vol. IV).

Yogyakarta: Pustaka Pelajar.

Dyer, L. (2004). Meningkatkan Kemampuan

Bicara Anak. Jakarta: Bhuana Ilmu Populer.

Herdiansyah, H. (2013). Wawancara, Observasi dan Focus Groups Sebagai Instrumen Penggalian Data Kualitatif. Depok: Rajagrafindo Persada.

Hurlock, E. B. (2012). Psikologi Perkembangan. Jakarta: Erlangga.

Indriari, E. (2011). Kesulitan Bicara dan Berbahasa Pada Anak : Terapi dan Strategi Orang Tua. Jakarta: Prenada. Khailullah. (2004). Media Pembelajaran Bahasa. Yogyakarta: Aswaja Pressindo. Moleong, L. J. (2013). Metodelogi Penelitian Kualitatif. Bandung: Remaja Rosdakarya. Nasution. (2009). Metode Reasearch (Penelitian Ilmiah). Jakarta: Bumi Aksara.

Nawawi, A. (n.d.). Stimulasi dan Intervensi (Modul).

Nurima, E. (2010, Mei). Anak Terlambat Bicara, Normalkah? Eka News, hal. 1.

Santrock, J. W. (2012). Perkembangan Masa Hidup (Edisi Ketigabelas jilid I). Jakarta: Erlangga. 
OPEdagogıa : Jurnal IImu Pendidikan

Seotjiningsih. (1995). Tumbuh Kembang Anak. Jakarta: Penerbit Buku Kedokteran EGC.

Seotjiningsih, C. H. (2012). Perkembangan Anak Sejak Pertumbuhan Sampai Dengan Kanak-kanak Akhir. Jakarta: Prenada.

Somantri, S. (2007). Psikologi Anak Luar Biasa. Bandung: Refika Aditama.

Sugiyono. (2013). Metode Penelitian Pendidikan (Pendekatan Kuantitatif, Kualitatif dan R\&D). Bandung: Alfabeta.

Susiliana,R dan Riyana,C. (2008). Media Pembelajaran. Bandung : Jurusan Kurtekpend FIP UPI

Wiyani, N. A. (2014). Buku Ajar Penanganan Anak Usia Dini Berkebutuhan Khusus. Yogyakarta: ArRuzz Media.

Clinic, G. (2012, Desember 22). Tanda Gejala Down Syndrome dan Gangguan yang Menyertai. [Online] Tersdia : 1 [08 Nopember 2014]
Judarwanto, W. (2009, April 25). Tanda dan Gejala Gangguan Perkembangan Fungsi Motorik, Motorik Oral dan Gangguan PerilakuyangSering Dikaitkan padaAnak dengan Gangguan Bicara dan Bahasa. [Online] Tersedia : http://speechclinic. wordpress.com/2009/04/25/tanda-dangejala-gangguan-perkembangan-fungsimotorik-motorik-oral-dan-gangguanperilaku-yang-sering-dikaitkan-padaanak-dengan-gangguan-bicara-danbahasa/ [08 Nopember 2014]

Pruthi, G. (2007). Language Development in Children with Mental Retardation. [Online] Tersedia : http://goertzel. org/dynapsyc/2007/Language \%20 development.htm [07 Januari 2015] 